\title{
Anthropology Journals
}

\section{from Routledge}

We publish a wide range of Anthropology journals to help you with your research.

Anthropological Forum

Anthropology \& Medicine

The Asia Pacific Journal of Anthropology

Ecology of Food and Nutrition

ethnos: Journal of Anthropology

Folklore

Food and Foodways

History \& Anthropology

Identities
Journal of Development Studies

Medical Anthropology

Mortality

Nationalities Papers

Postcolonial Studies

Religion, State and Society

Reviews in Anthropology

Storytelling, Self \& Society

Visual Anthropology

\section{Find Out More}

Each of our journals has a dedicated website with information about

- the journal's aims and scope -

- free access to articles and other special offers -

- recent and forthcoming themed issues -

- calls for papers for general and themed issues -

- subscribing and library recommendations -

- how to submit your paper .

Visit the website to find a journal to match your area of interest today!

www.informaworld.com/anthropology

You can now follow our Anthropology titles on Twitter at twitter.com/routledge_anth

Routledge

Taylor \& Francis Group 


\section{Anthropology Journals from Routledge}

\section{Anthropology Arena}

Find out more about our journals at our Anthropology Arena, where we post the latest news, special offers, calls for papers and free online access. Our free online access offers are a great place to start your research because you'll be able to read a selection of articles from our journals even if your institution doesn't subscribe.

\section{www.informaworld.com/anthropology}

\section{Twitter}

Do you want to keep up-to-date with the most recent news from our range of anthropology titles, but don't have time to visit the Anthropology Arena regularly? You can now follow our anthropology titles on Twitter too!

\section{www.twitter.com/routledge_anth}

\section{Newsletter}

Do you prefer a more traditional newsletter for your book and journal information?

If so, register for our Anthropology eUpdates. You'll receive four issues each year directly to your inbox with a roundup of the most recent news and offers.

\section{www.informaworld.com/eupdates}

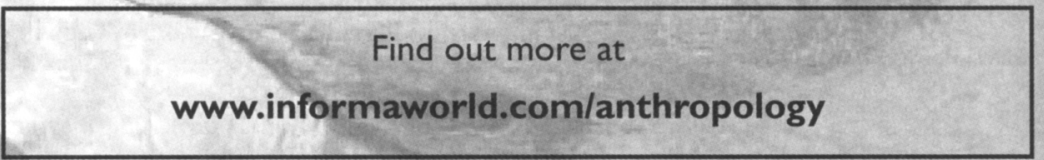




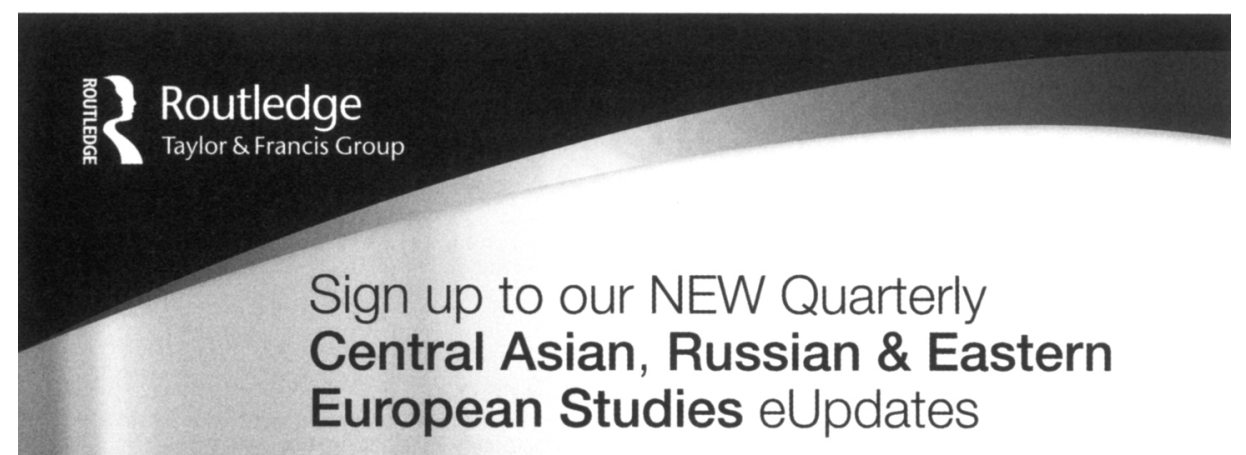

\section{eUpdate Newsletter}

Register your email address at www.tandf.co.uk/journals/eupdates.asp to receive the new Central Asian, Russian \& Eastern European Studies eUpdates, a quarterly newsletter that keeps you informed about journals, books, conferences and other news within your areas of interest.

Subscribers to eUpdates will receive information on the following:

- Routledge journals and books

- Special offers

- Sample articles

- Call for papers

- Promotional campaigns

- Forthcoming conferences and meetings

\section{Cupdates}

\section{Table of Contents Alerts}

A free journal contents alerting service is available for all Routledge Central Asian, Russian \& Eastern European Studies journals. By subscribing to this service, you will receive table of contents alerts as new journal issues are published as well as specific news and offers relating to the journal.

www.informaworld.com/alerting 
Nationalities Papers is the leading journal on nationalism, ethnicity, ethnic conflict and national identity in Central Europe, the Balkans, the former Soviet Union, the Caucasus, the Turkic world and Central Eurasia. Furthermore, the journal also publishes contributions on theories of nationalism, comparative studies of nationalism, and transand supranational aspects of interethnic relations and national identity. The journal publishes timely, high quality articles from a variety of disciplines, including history, political science, sociology, anthropology, and literature.

Nationalities Papers is the journal of the Association for the Study of Nationalities, bringing together scholars worldwide working on nationalism and ethnicity, Central and Eastern Europe, the Balkans and Eurasia.

All articles have undergone rigorous peer review, based on initial editor screening and double-blind refereeing by a minimum of two anonymous referees.

The journal welcomes submissions from multiple disciplines and different methodological approaches from scholars around the world. In addition to individual paper submissions, the journal also welcomes proposals for special symposia (3-5 articles) on specific regional or disciplinary themes. All symposia will undergo the same peer review process as other articles. Articles should be between 8,000 and 10,000 words in length (including notes and bibliography).

Inquiries. Direct all inquiries regarding articles and special symposia to the Editor: f.bieber@kent.ac.uk.

Electronic Submission. All submissions should be made online at the Nationalities Papers ScholarOne Manuscripts site (http://mc.manuscriptcentral.com/CNAP). New users should first create an account. Once a user is logged onto the site submissions should be made via the Author Centre. Authors should prepare and upload two versions of their manuscript. One should be a complete text, while in the second all document information identifying the author should be removed from files to allow them to be sent anonymously to referees. When uploading files authors will then be able to define the non-anonymous version as "File not for review".

Note to authors. Please make sure your contact address information is clearly visible on the outside of all packages you are sending to Editors. Authors should be mindful of the need to identify and reference quoted material - text, tables, and figures - clearly and consistently, and to secure written permission from the copyright holder as appropriate. http://tandf.tandf.co.uk/journals/ethics.asp

Offprints. Corresponding authors can receive 50 free reprints, free online access to their article through our website (www.informaworld.com) and a complimentary copy of the issue containing their article. Complimentary reprints are available through Rightslink ${ }^{\circledR}$ and additional reprints can be ordered through Rightslink ${ }^{\circledR}$ when proofs are received or alternatively on our journals website. If you have any queries, please contact our reprints department at reprints@tandf.co.uk

Copyright. It is a condition of publication that authors assign copyright or license the publication rights in their articles, including abstracts, to The Association for the Study of Nationalities. This enables us to ensure full copyright protection and to disseminate the article, and of course the Journal, to the widest possible readership in print and electronic formats as appropriate. Authors retain many rights under the Taylor \& Francis rights policies, which can be found at www.informaworld.com/authors_journals_copyright_position. Authors are themselves responsible for obtaining permission to reproduce copyright material from other sources.

\section{THE ASSOCIATION FOR THE STUDY OF NATIONALITIES}

New York

Phone: +1 2128546239

President

Vice-Presidents

Executive Director:

Secretary:

Chair of the Advisory Board:

President Emeritus:

Convention Program Chair:

European Conferences:

Executive Committee:
Dominique Arel, University of Ottawa, Canada

Zsuzsa Csergo, Queen's University, Canada

Vejas Liulevicius, University of Tennessee, USA

Ines Murzaku, Seton Hall University, USA

Gordon N. Bardos, Harriman Institute, Columbia U, USA

Lisa Koriouchkina, Brown University, USA

David Crowe, Elon University, USA

Michael Rywkin, City College, USA

Sherrill Stroschein, University College London, UK

Stefano Bianchini, University of Bologna, Italy

Dominique Colas, SciencesPo, Paris, France

Hugh Agnew, George Washington University, USA

Lowell Barrington, Marquette University, USA

Mark Beissinger, Princeton University, USA

Florian Bieber, University of Kent, UK

Nina Caspersen, Lancaster University, UK

Bhavna Dave, School of Oriental \& African Studies, UK

Dmitry Gorenburg, AAASS, Cambridge, USA

Alexandra Goujon, University of Bourgogne, Dijon, France

Charles King, Georgetown University, USA

André Liebich, Graduate School of International Studies, Switzerland

Troy McGrath, Russian State University for the Humanities, Moscow, Russia

Michaela Pohl, Vassar College, USA

Steve Sabol, University of North Carolina, Charlotte, USA

Oxana Shevel, Tufts University, USA

Stefan Wolff, University of Nottingham, UK

Myroslava Znayenko, Rutgers University, USA 


\section{Contents}

\section{Analysis of Current Events}

Doing more with less: the Justice and Development Party (AKP), Turkish elections, and the uncertain future of Turkish politics

Kristin Fabbe

\section{Articles}

Russian Orthodox concordat? Church and state under Medvedev

Irina Papkova

Dual citizenship and sovereignty

Szabolcs Pogonyi

Representations of the past in the Estonian Russian-language press: "own" or diaspora memory?

Multiculturalism, memory, and ritualization: Ukrainian nationalist monuments in Edmonton, Alberta

Per A. Rudling

Silesian in the nineteenth and twentieth centuries: a language caught in the net of conflicting nationalisms, politics, and identities

Tomasz Kamusella

Exit Yugoslavia: longing for mononational states or entrepreneurial manipulation?

Rudi Klanjšek and Sergej Flere

Transnational minorities challenging the interstate system: Mingrelians, Armenians, and Muslims in and around Abkhazia

Kimitaka Matsuzato

\section{Book Symposium}

Milica Uvalic, Serbia's transition: towards a better future

Jan Svejnar; Tea Trumbic; Susan L. Woodward; Milica Uvalic

Book Reviews 